\title{
PRELIMINARY CHECKLIST OF FRESHWATER FISHES OF ULU PAIP ECO-PARK FOREST, KEDAH, PENINSULAR MALAYSIA
}

\author{
MOHAMAD AQMAL-NASER ${ }^{1}$ and AMIRRUDIN B. AHMAD ${ }^{1,2^{*}}$ \\ ${ }^{1}$ Biodiversity and Ecology Research Group, Faculty of Science and Marine Environment, \\ Universiti Malaysia Terengganu, 21030 Kuala Nerus, Terengganu \\ ${ }^{2}$ Institute of Tropical Biodiversity and Sustainable Development, \\ Universiti Malaysia Terengganu, 21030 Kuala Nerus, Terengganu \\ *E-mail:amirrudin@umt.edu.my
}

Accepted 11 January 2021, Published online 30 March 2021

\begin{abstract}
This report is the first on freshwater fishes of Ulu Paip Eco-Park Forest, Kedah, which aims to document the fish species richness in this recreational forest. All species were collected from the main stream, Sungai Karangan, and its unnamed tributaries. In total, 20 species of fishes from 10 families were recorded. Cyprinidae is the most dominant family with six species followed by Danionidae with three species. Other families contribute at least one species each. Most of the species recorded here are commonly found in the northern part of Peninsular Malaysia. Further studies should be expected to record more species and the utilization of various sampling gear such as electro fishing technique would be able to record the true species richness of fishes in this area.
\end{abstract}

Key words: Species richness, Ulu Paip, logging, Gunung Bongsu, recreational forest

\section{INTRODUCTION}

Peninsular Malaysia was blessed with countless numbers of small to large streams within its catchment areas. These water-bodies were able to sustain diverse species of aquatic organisms, particularly freshwater fish species. To date, about 289 freshwater fish species were known to be existed in Peninsular Malaysia (Zakaria-Ismail et al., 2019), and the number was expected to increase especially for the cryptic species with the advancement in the genetic studies. There were few studies on fish species richness has been conducted in the recreational areas (Shah et al., 2009; Ahmad et al., 2018a) as well as in the stream associated with the farm field (Ahmad et al., 2018b). Based on the studies, Barbodes binotatus, Hampala macrolepidota, and Mystacoleucus obtusirostris were among the common species that inhabit the small stream's habitat in the recreational areas. There were 22 species of fishes were recorded by Ahmad et al. (2018b) in the farm field area while recreational areas

* To whom correspondence should be addressed. had recorded a diverse number of fish species which were 32 species (Ahmad et al., 2018b) and 37 species (Shah et al., 2009), respectively.

However, the fish species richness in Ulu Paip Eco-Park Forest that is situated within the Gunung Bongsu Forest Reserve was yet to be explored. This recreational forest is surrounded by agricultural areas including oil palm and rubber plantations, and small orchards thus, prone to the indirect effect of wastewater run-off and chemical discharges sporadically. Also, the illegal logging activity at the upper stream has diminished some of the pristine habitats within this area especially the stream itself. Given its large area for flora and fauna to flourish, only one study on amphibians has been conducted at this site to date (Shariza \& Ibrahim, 2014). Looking at the rapid deterioration of the surrounding areas and the water quality of the stream, it would be supremely urgent to obtain some information on the ichthyofauna living here. This rapid assessment of ichthyofauna in this recreational area was carried out to document the fish species richness as baseline information that may be useful for habitat management and conservation plans in the future. 


\section{MATERIALS AND METHODS}

Ulu Paip Eco-Park Forest, Kedah is a lowland dipterocarp forest located in the north-eastern parts of Gunung Bongsu Forest Reserve, $20 \mathrm{~km}$ from Kulim town, and can easily be assessed by road. The main stream, Sungai Karangan is originated from Gunung Bongsu (658 $\mathrm{m}$ above sea level), flows into Sungai Muda through Sungai Sedim before being discharged into the Straits of Malacca. The stream is shallow with sandy substrate punctuated mainly by boulder and pebble beds. The riparian vegetation canopy covered most of the stream banks but the middle section of the stream is often exposed, allowing the penetration of sunlight during the day to reach the bottom depth of the stream.

Fishes were collected from Sungai Karangan (5²3’37.1" N, 10040’00.4" E) which flows within the Ulu Paip Eco Park Forest (Figure 1). The fish collection was carried out using a hand-held push net (mesh size $3 \mathrm{~mm}$ ) and cast net (mesh size $10 \mathrm{~mm}$ ) during four sampling occasions (April, May, July, and September 2014). All the fishes were placed in an aerated bucket filled with stream water to reduce stress and mortality. Most of the species were identified in situ and released back into the stream upon identification. All the species were identified into species level using standard taxonomic references of Rainboth (1996) and Zakaria-Ismail et al. (2019) and van der Laan and Fricke (2020) while the current taxonomic of Cypriniformes follows Tan and Armbruster (2018). The familial arrangement follows Kottelat (2013). Voucher specimens were collected whenever possible and fixed in $10 \%$ formalin. After two weeks, voucher specimens were transferred into $70 \%$ alcohol for long term storage and deposited at General Laboratory, Universiti Malaysia Terengganu.

\section{RESULTS AND DISCUSSION}

A total of 20 species from 10 families of freshwater fishes was recorded during the surveys in Ulu Paip Eco Park Forest (Table 1). Family Cyprinidae is the dominant with six species, followed by Danionidae (three species), Bagridae, Mastacembelidae, and Channidae with two species each while other five families - Sisoridae, Siluridae, Clariidae, Zenachopteridae, and Oshpronemidae with one species each.

The mountainous area in Kedah holds numerous headwater streams which were not studied extensively except in Gunung Jerai (Ahmad et al., 2006; Shah et al., 2009) and Ulu Muda Forest Reserve (Sah et al., 2012; Lee et al., 2013). Most of the streams located in the recreational area thus, prone to various disturbances including pollution by humans, agricultural waste, and logging. Several streams in Ulu Muda Forest Reserve were already been affected by logging activities (Rahman, 2018) with no exception in Ulu Paip Eco-Park Forest (Rahman, 2017). Some of the fish species which cannot tolerate the environmental changes will not have the chance to survive due to habitat degradation, leading to the reduction of fish fauna as this study managed to collect only 20 species of freshwater fishes. We expect that more fish species will be collected with the continuous collection and efficient sampling techniques especially using electro fishing to collect bottom dweller and cryptic species.

Families Cyprinidae and Danionidae made up the major proportion of fish fauna in this area. Both families were known as the most dominant families of freshwater fishes in Peninsular Malaysia (ZakariaIsmail et al., 2019). Previously, species from the family Danionidae was placed into family Cyprinidae but later they were split which family Danionidae consist of species that include rasboras, danios, and their allies (Tan \& Armbruster, 2018), which did not have the Y-shaped ligament that connecting the ethmoid and kinethmoid bones (Liao \& Kullander, 2013). The family composition between this study and other studies elsewhere was different since different sampling methods were used which could be biased for the direct comparison. There is one interesting species complex namely Barbodes cf. binotatus, that is widely distributed in Peninsular Malaysia but needs further taxonomic clarification especially using the molecular approaches (see Fahmi-Ahmad et al., 2020). Other species recorded were common species that can be found in the hilly streams throughout Peninsular Malaysia. One of the most abundant species found here was Devario regina (family Danionidae) that the distribution was limited to the northeastern part of Peninsular Malaysia until as far north as Thailand (Ahmad et al., 2006).

Logging activities can directly affect the sediment load in the streams that might affect fish species richness as the reduction of water qualities. According to Jones III et al. (2001), logging or removal of riparian forest vegetation will reduce fish diversity and ability to fertilize the egg since the sediment load is higher. Hence, the egg will not firmly attach or deposit on the spawning site. However, Rowe et al. (2002) and Dias et al. (2010) found that there was no significant effect on fish assemblages in both logged and non-logged forests in their studies. Plus, in Malaysia, a study by Martin-Smith (1998) also found only a subtle effect of timber extraction on fish diversity. In the point of conservation, this could be a good indicator that fish can tolerate intermediate disturbance but it should 


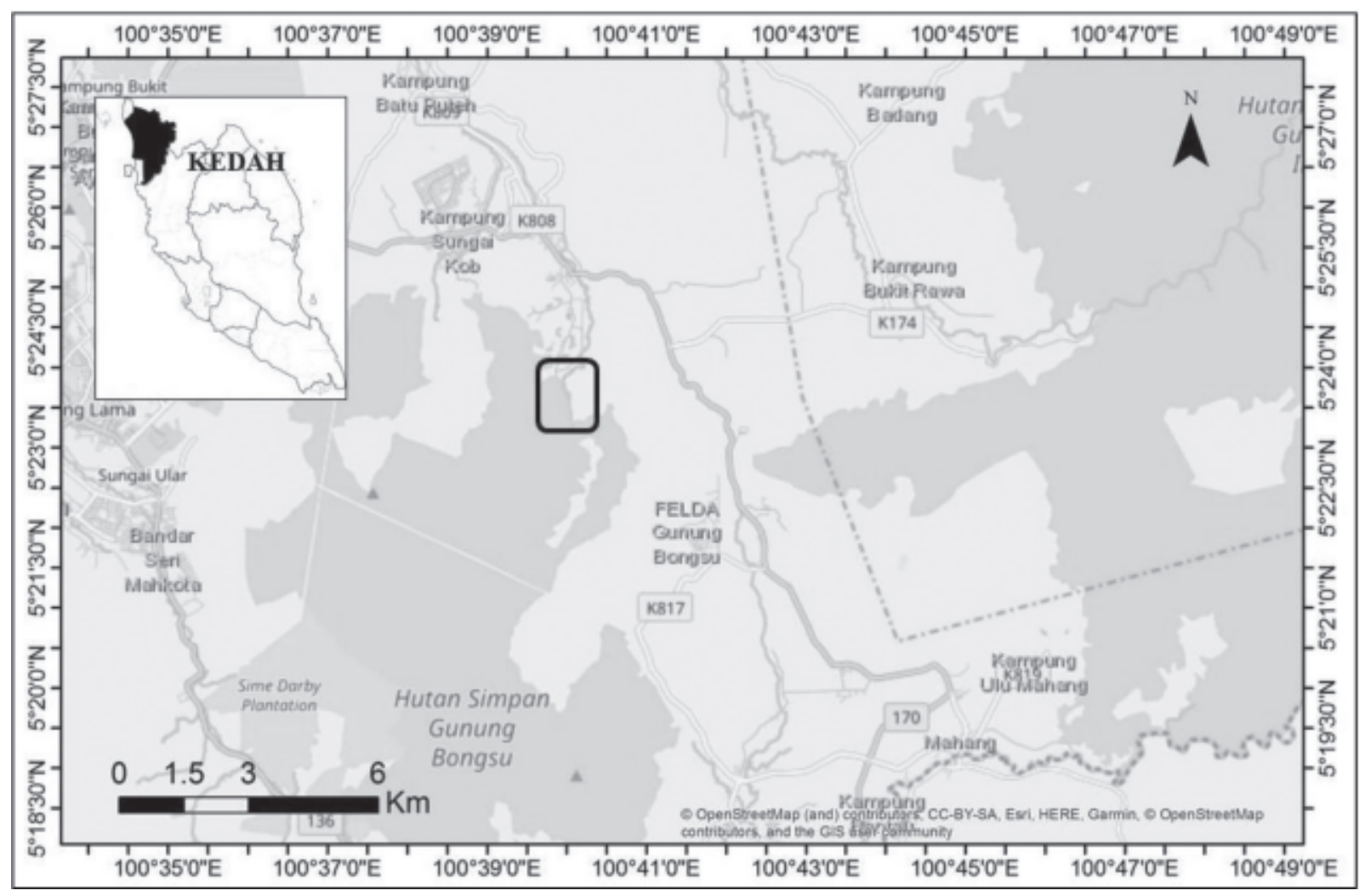

Fig. 1. The map of Peninsular Malaysia (inset) showing the state of Kedah (shaded region) where the study area is located. The main map showing the surrounding lands of Ulu Paip Eco Park (black rectangle) is located within Gunung Bongsu Reserve Forest.

Table 1. Checklist of fishes recorded from Ulu Paip Forest Eco-Park, Kedah

\begin{tabular}{|c|c|c|}
\hline Order & Family & Species \\
\hline \multirow[t]{2}{*}{ Cypriniformes } & Cyprinidae & $\begin{array}{l}\text { Barbodes cf. binotatus } \\
\text { Barbodes lateristriga } \\
\text { Hampala macrolepidota } \\
\text { Ceratogarra cambodgiensis } \\
\text { Mystacoleucus obtusirostris } \\
\text { Neolissochilus hendersoni }\end{array}$ \\
\hline & Danionidae & $\begin{array}{l}\text { Brachydanio albolineata } \\
\text { Devario regina } \\
\text { Rasbora vulgaris }\end{array}$ \\
\hline \multirow[t]{4}{*}{ Siluriformes } & Sisoridae & Glyptothorax fuscus \\
\hline & Siluridae & Silurichthys schnederi \\
\hline & Clariidae & Clarias leiacanthus \\
\hline & Bagridae & $\begin{array}{l}\text { Batasio fluviatilis } \\
\text { Hemibagrus capitulum }\end{array}$ \\
\hline Beloniformes & Zenarchopteridae & Hemirhamphodon pogonognathus \\
\hline Synbrachiformes & Mastacembelidae & $\begin{array}{l}\text { Macrognathus maculatus } \\
\text { Mastacembelus tinwini }\end{array}$ \\
\hline \multirow[t]{2}{*}{ Anabantiformes } & Osphronemidae & Betta pugnax \\
\hline & Channidae & $\begin{array}{l}\text { Channa lucius } \\
\text { Channa limbata }\end{array}$ \\
\hline
\end{tabular}




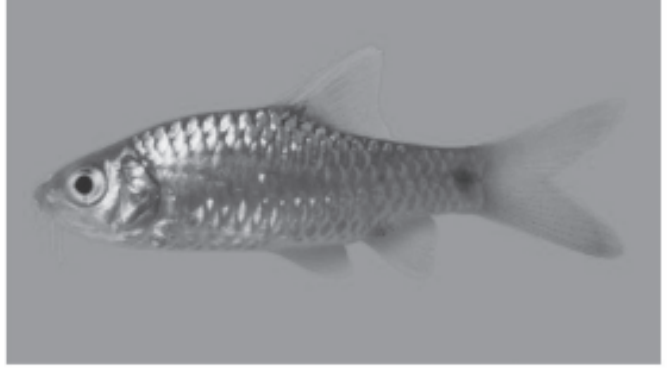

Plate 1. Barbodes cf. binotatus

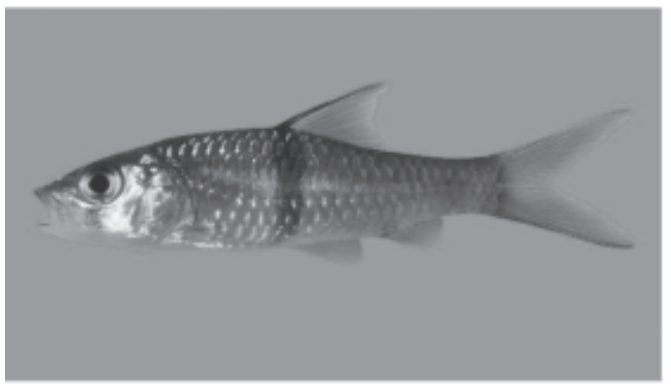

Plate 3. Hampala macrolepidota

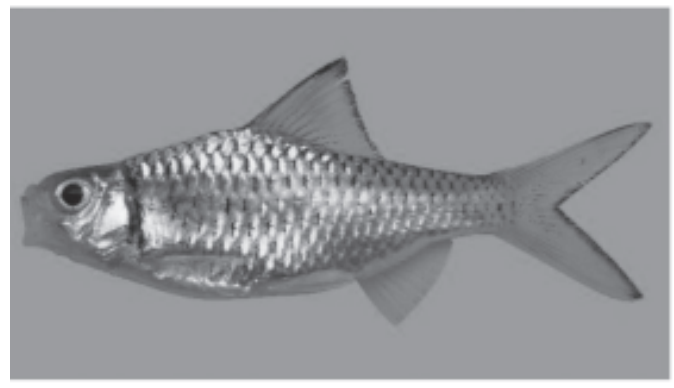

Plate 5. Mystacoleucus obtusirostris

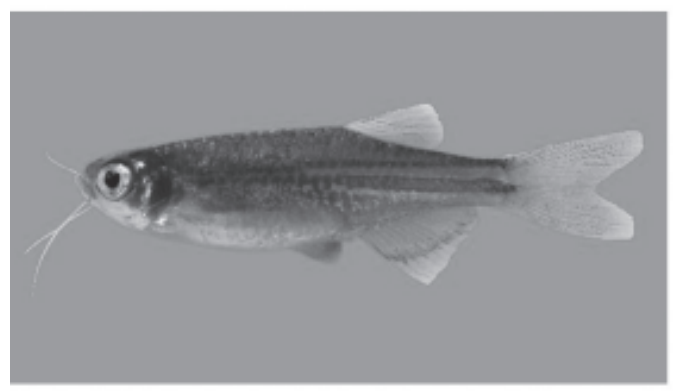

Plate 7. Brachydanio albolineata

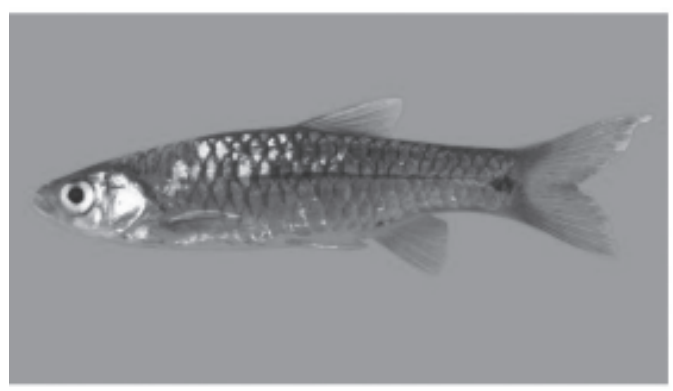

Plate 9. Rasbora vulgaris

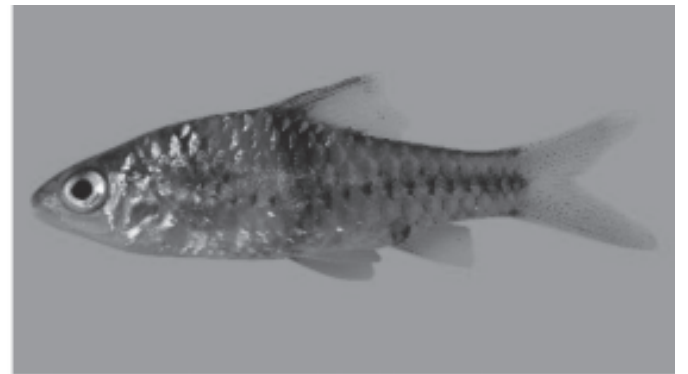

Plate 2. Barbodes lateristriga

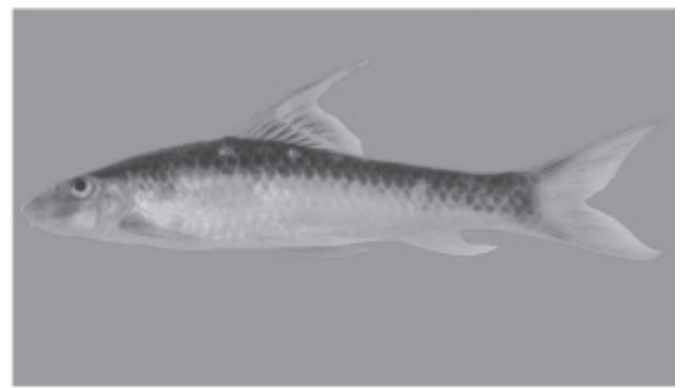

Plate 4. Ceratogarra cambodgiensis

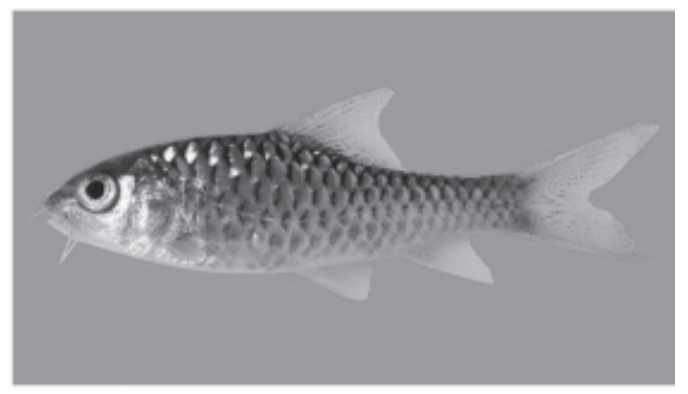

Plate 6. Neolissochilus hendersoni

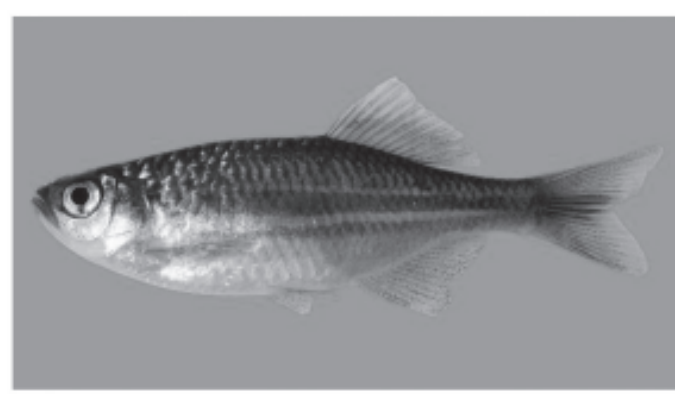

Plate 8. Devario regina

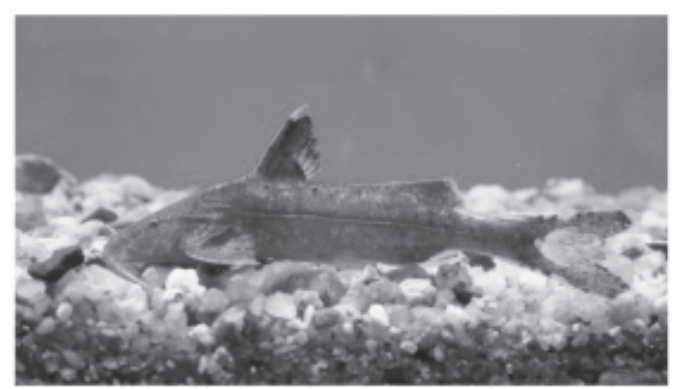

Plate 10. Glyptothorax fuscus 


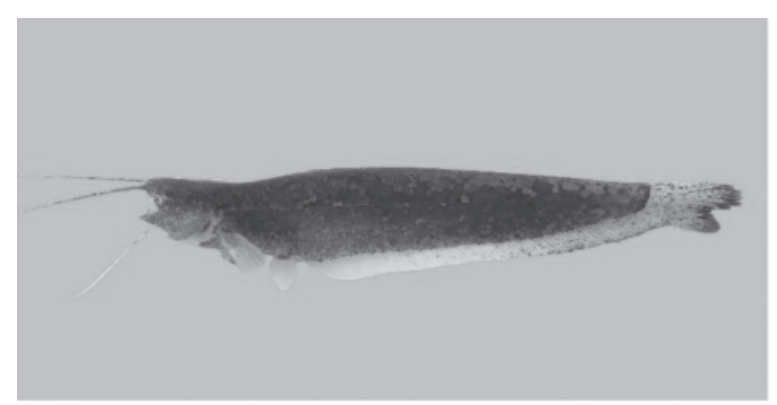

Plate 11. Silurichthys schneideri

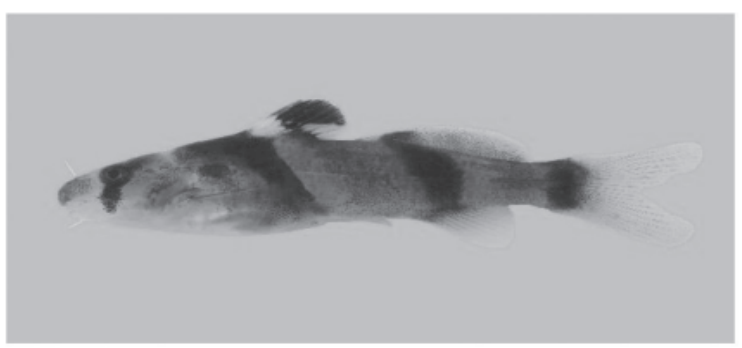

Plate 13. Batasio fluviatilis

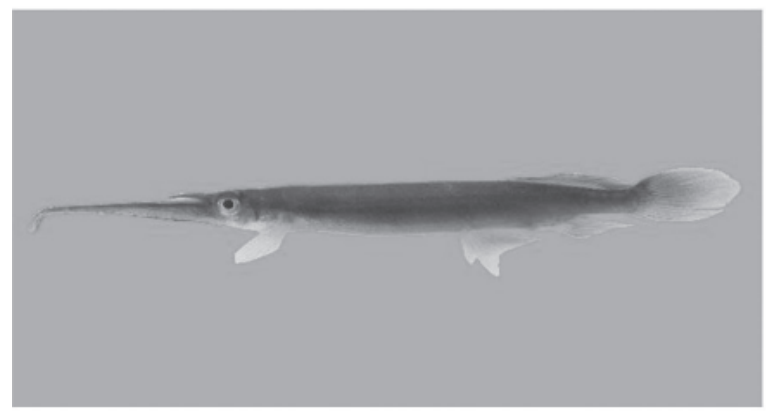

Plate 15. Hemirhamphodon pogonognathus

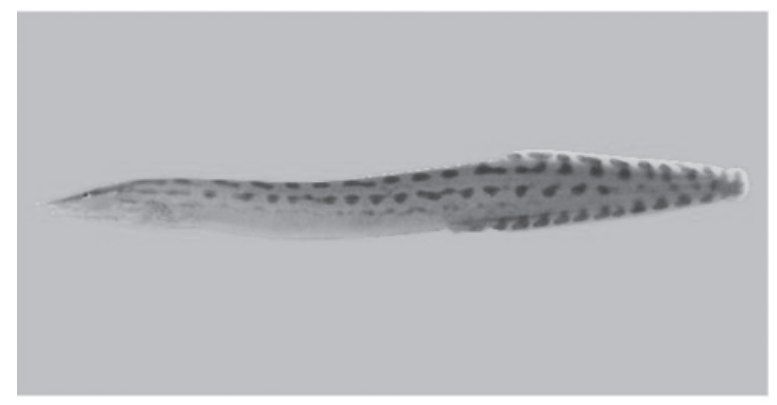

Plate 17. Mastacembelus tinwini

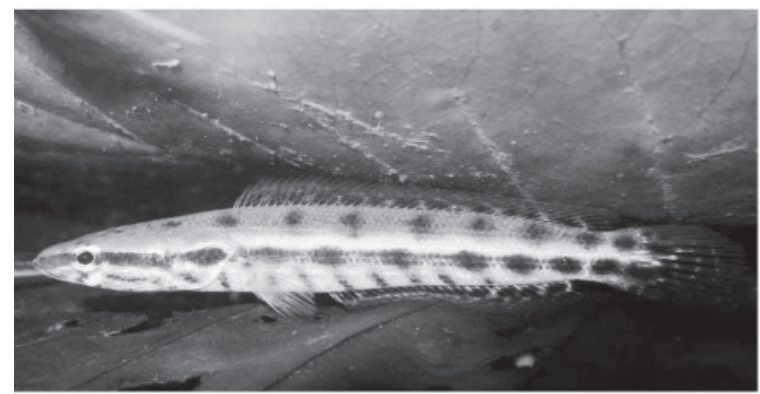

Plate 19. Channa lucius

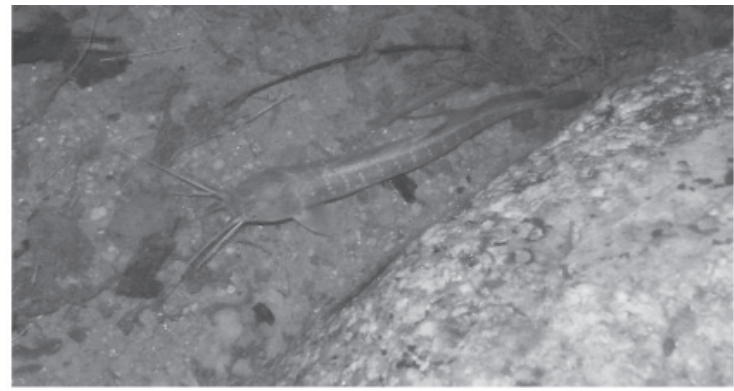

Plate 12. Clarias leiacanthus

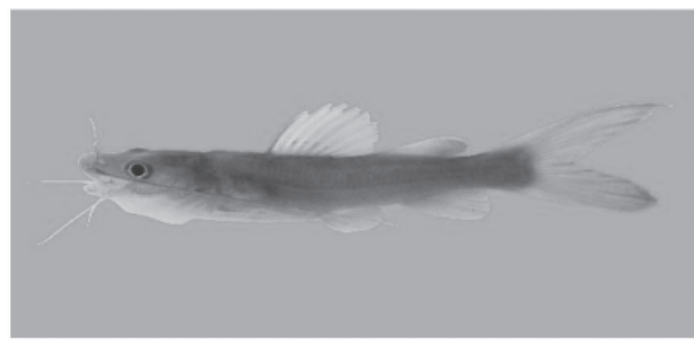

Plate 14. Hemibagrus capitulum

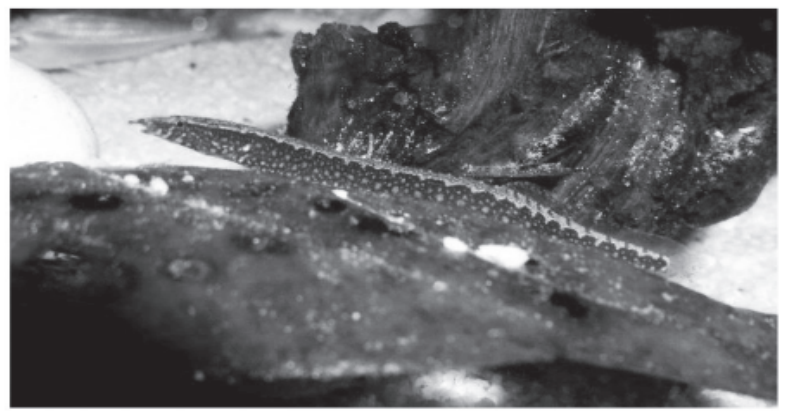

Plate 16. Macrognathus maculatus

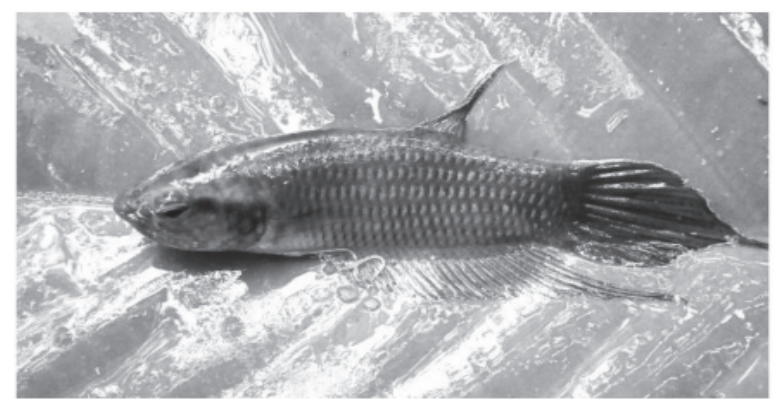

Plate 18. Betta pugnax

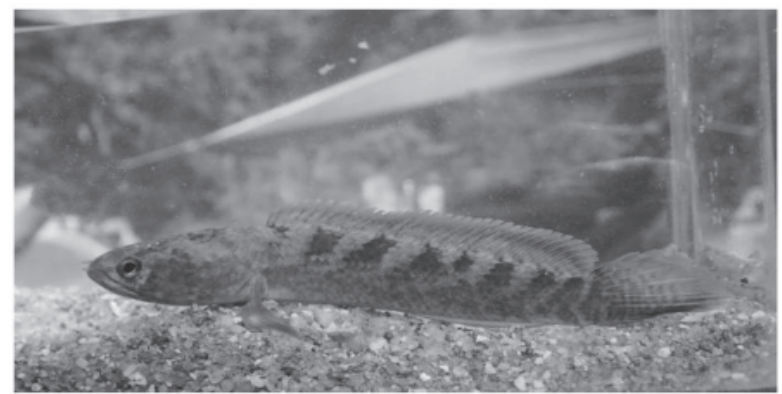

Plate 20. Channa limbata 
not be a reason to allow for more land use in this forest reserve since river rehabilitation needs a longer time for recovering process.

\section{Fish checklist of Ulu Paip Eco-Forest Park, Kedah}

\section{Order Cypriniformes}

\section{Family Cyprinidae \\ Barbodes cf. binotatus (Valenciennes, in Cuvier \& Valenciennes 1842)}

Plate 1

Material examined: 3 ex., $50-70 \mathrm{~mm}$ SL, collected from the main stream in the stagnant water using a cast net, coll: M. Aqmal-Naser, 08 April 2014. UMTZC 8001

Remarks: The species has a broad and round snout with four barbels. Possess a black round spot below the dorsal fin base but not extended downward to mid-body and at the middle of caudal peduncle on the base of the caudal fin, somewhat similar to what has been identified by Fahmi-Ahmad et al. (2020) as B. binotatus-type B (see Table 1 in Fahmi-Ahmad et al., 2020). Juveniles and some of the subadults may have $2-4$ midlateral spots either rounded or slightly elongated (Kottelat et al., 1993). Morphospecies from the northern part of Peninsular Malaysia is currently referred to as "Barbodes cf. binotatus" since the real species (Barbodes binotatus) is said to be restricted to Java or Java origins (Kottelat, 2013). A similar form has been reported from the state Perak (see Ng et al., 2019). The species was reported as Puntius banksi by Ahmad and Samat (2005) from Perlis State Park and Systomus binotatus by Ahmad and Lim (2006) from Langkawi Island may be referring to this species. This species may form a species complex (FahmiAhmad et al., 2020) and could represent more than one species. Molecular works are urgently needed and are hoping to be able to resolve the taxonomic and systematic problem of this species and species with its complexity.

\section{Barbodes lateristriga (Valenciennes, in Cuvier \& Valenciennes 1842)}

\section{Plate 2}

Material examined: 1 ex., $30 \mathrm{~mm}$ SL, from riverbank' vegetation, coll: M. Aqmal-Naser. 08 April 2014. UMTZC 8002

Remarks. A juvenile, has modest body depth, a midlateral line on the posterior part of the body extended to the caudal fin, two vertical bars visible on the anterior half of the body. Body yellowish with black markings. Complete lateral line with $21-23$ scales.
Inhabit slow-moving water or pools. Most of the juveniles were seen in this area preferring shallow and slow-flowing water but adults preferring deeper and fast-flowing waters. In all, this species has six different body markings - 'Johor form', 'Selangor form', 'Muar River form', 'Pahang and Kelantan form', 'Perak form', and 'Perlis and Kedah form' (Tweedie, 1961). The specimen from this study site belongs to the Perlis and Kedah form (Tweedie, 1961). The adult has broad vertical bars and descending low on the sides. The anterior horizontal bar is consisting of few black spots. The fish from Ulu Paip is highly similar to B. lateristriga from Langkawi Island (reported by Ahmad \& Lim, 2006 as Systomus lateristriga) and highly probably similar to those reported from Perlis State Park by Ahmad and Samat (2005) as Puntius lateristriga. Yet again, this species might require a molecular study since this species in Peninsular Malaysia is thought to be influenced by a geographical barrier (Kamaruddin \& Nor, 2010). This species is also found on large islands in Peninsular Malaysia such as Langkawi (Ahmad \& Lim, 2006) and Tioman Islands where it is only the naturally existing cyprinid on the island (Tan et al., 2015; Aqmal-Naser \& Ahmad, 2018a). Until further studies are done, this species shows a wide distribution range in Peninsular Malaysia.

\section{Hampala macrolepidota Kuhl \& van Hasselt 1823}

Plate 3

Material examined: 2 ex., 56 and $150 \mathrm{~mm} \mathrm{SL}$, collected fast flowing water in the main stream using a cast net, coll: M. Aqmal-Naser, 02 September 2014. UMTZC 8003

Remarks. Posses black bar between pelvic fin and anterior of the dorsal fin. Dorsal and caudal fins with distinct black submarginal longitudinal bands. The species can be found throughout the South Asian region including Thailand, Cambodia, Laos, Indonesia, and Malaysia (Peninsular Malaysia, Sabah, and Sarawak). There are four current species from the genus Hampala in Malaysia which are H. macrolepidota (in Peninsular Malaysia, Sabah and Sarawak), Hampala bimaculata (central and northern Sarawak, North Borneo, Sabah), Hampala sabana (Kinabatangan basin), and H. ampalong (Borneo) (Ryan \& Esa, 2006). Despite it is widely distributed, the population in Sabah and Sarawak are genetically similar to that found in Peninsular Malaysia. Hampala macrolepidota is a common predatory species that feed on small-sized species of various groups of organisms including fish, frogs, and invertebrates. Good for sport fishing however overfishing becomes the major threat for the species. 


\section{Ceratogarra cambodgiensis (Tirant 1884)}

Plate 4

Material examined: 1 ex., $170 \mathrm{~mm} \mathrm{SL}$, collected from the fast-flowing water within the boulders in the main stream, coll: M. Aqmal-Naser, 02 September 2014. UMTZC 8004

Remarks: Posses rostral barbels but without maxillary barbels, dark mid-lateral line with $30-35$ lateral scales, and absence of submarginal stripe at caudal fin (Rainboth, 1996). Possess two broad midlateral stripes, dorsal fin with two black bands, and well-developed tubercles on the snout during spawning season. The species is distributed in Thailand, Laos, Cambodia, Vietnam, and Peninsular Malaysia. Recently, the genus has been reassigned to Ceratogarra by Kottelat (2020) for both $G$. cambodgiensis and G. fascicauda. The identification of Garra spp. is puzzling especially in Southern Asia. Ceratogarra fascicauda that occur in Thailand can be further distinguished with this species by having black distal bands on its red caudal fin. Ceratogarra cambodgiensis is a common species and was found in the mountain streams. Algae-eater species are prone to population reduction due to logging activities that alter their food sources.

\section{Mystacoleucus obtusirostris (Valenciennes, in Cuvier \& Valenciennes 1842)}

Plate 5

Material examined: 4 ex., 45 - $70 \mathrm{~mm} \mathrm{SL}$, collected from the lower and upper stream using a cast net, coll: M. Aqmal-Naser, 02 September 2014. UMTZC 8005

Remarks: The species differ from its congener, Mystacoleucus chilopterus by having truncate or emarginate anal fin. Nearly all the scales have black crescent and have the distinct yellow color of the fins. The species has wider distribution including Myanmar, southwestern China, Thailand, Cambodia, Laos, Vietnam, Indonesia, Borneo, and Peninsular Malaysia. A common species but rarely seen in the aquarium trade. Ahmad and Samat (2005) reported this species as Mystacoleucus marginatus from Perlis State Park.

\section{Neolissochilus hendersoni (Herre 1940)}

\section{Plate 6}

Material examined: 2 ex., SL $56-210 \mathrm{~mm}$ SL, mainstream in the fast-flowing water, unnamed tributaries at the upper part of the main stream, coll: M. Aqmal-Naser, 02 September 2014. UMTZC 8006

Remarks: The species was collected from clear water and fast-flowing water. There are three recognized species from the genus Neolissochilus in Peninsular Malaysia - Neolissochilus hendersoni, Neoliccsochilus soro, and Neoliccsochilus soroides (Zakaria-Ismail et al., 2019). Neolissochilus soroides can be distinguished by having 23 - 25 lateral line scales and $8-10$ predorsal scale compared to Neoliccsochilus soro which has $24-25$ lateral line scales and $8-9$ predorsal scales. While Neolissochilus hendersoni has 21 - 22 lateral line scales and $7-8$ predorsal scale. Neolissochilus hendersoni were recorded in Penang Island, Kedah, and Kelantan drainages while Neolissochilus soroides are a common species throughout Peninsular Malaysia (Khaironizam et al., 2015). It was also recorded in Java (Kottelat et al., 1993), Thailand (Rainboth, 1996), and Anambas Island (Tan \& Lim, 2004).

\section{Family Danionidae}

\section{Brachydanio albolineata (Blyth 1860)}

Plate 7

Material examined: 3 ex., $27-350 \mathrm{~mm}$ SL, main stream and all unnamed tributaries in the area, coll: M. Aqmal-Naser, 02 September 2014. UMTZC 8007

Remarks: Species from this genus are known as the "Danio dangila species group" comprised of previously known species - Danio dangila, Danio rerio, Danio nigrofasciatus, and Danio albolineatus (Fang, 2003). The species-complex of this genus and species remain to be solved. They have A-stripe on their anal fin rays, enlarged lamellar nasal, and two or more stripes on caudal-fin rays (Fang, 2003). A study by Fang et al., (2009) concluded that Danio dangila is a sister group to all genus Celestichthys and Brachydanio, hence was not placed under genus Brachydanio (see Kottelat, 2013), could be two different species. According to Kottelat (2001), this species can be differentiated from other species by having an incomplete lateral line with $5-7$ pored scales, and the rostral barbels extend beyond the eye. The type locality of this species (reported as Danio teweediei) is in Sungai Petani, Kedah while the type locality of specimens reported as Nuria albolineata is in Tenasserim, Burma (see Kottelat, 2013) and they could be two different species. The current distribution of the species is wider including Myanmar, Thailand, Laos, Cambodia, Vietnam, Peninsular Malaysia, and Sumatra until further validation of the species nomenclature and distribution. A common ornamental fish species. They inhabit small and pristine tributaries in this area. The species also has been reported from the rice field (Aqmal-Naser \& Ahmad, 2018b). Reported in Langkawi as Danio albolineatus (Ahmad \& Lim, 2006). 


\section{Devario regina (Fowler 1934)}

Plate 8

Material examined: Kedah 5 ex., $34-62$ mm SL, main stream in all types of habitat, coll: M. Aqmal-Naser, 08 April 2014. UMTZC 8008

Remarks: Species from this genus have P-stripe which is extended into the mid-caudal-fin rays, with a short maxillary barbell and sometimes absent for certain species (Fang, 2003). It was suggested that genus Devario is for larger species whereas genus Danio for smaller species but not applied to all species (Kottelat, 2013). Devario regina has a compressed body with more than 11 branched dorsal rays. Body consists of $3-4$ blue longitudinal bands. Frequently found in fast flowing water and usually can be seen schooling in a group more than five individuals. Abundant in the pristine streams and the distribution of this species is restricted to northwestern parts of Peninsular Malaysia (including some islands) to as far north as Thailand and probably not reaching south of Sungai Perak, in Peninsular Malaysia (Ahmad \& Lim, 2006).

\section{Rasbora vulgaris Duncker 1904}

\section{Plate 9}

Material examined: 3 ex., 62 - 74 mm SL, mainstream in slow-flowing water, coll: M. Aqmal-Naser, 02 September 2014. UMTZC 8009

Remarks: Species from this group were moved from Sumatrana-group into the $R$. paviana-group comprising of five species namely Rasbora paviana, Rasbora vulgaris, Rasbora notura, Rasbora hobelmani, and Rasbora dorsinotata which were distributed in the Malay Peninsula and Indochina (Kottelat, 2005). The species from this group has a mid-lateral stripe on each side of the body and blotch at the caudal peduncle but is not circumscribed (Lumbantobing, 2014). Also, Kottelat (2005) stated that the member of this group has diamond-shaped blotch and restricted to Asia. Lumbantobing (2014) then assert that this group has high variations of the blotch, varied position, and intensity thus, should be re-classified into Sumatrana-group with a more comprehensive study to solve the taxonomic confusions. Rasbora paviana can be differentiated from Rasbora vulgaris by having a black lateral line from the operculum to the base of the caudal fin (Zakaria-Ismail et al., 2019) while, Rasbora vulgaris in this study has a black lateral line behind the operculum and ending in front of the caudal peduncle blotch. The species can be found in various types of habitat including slow to moderate water current as well as stagnant water. The species is distributed throughout Thailand, Laos, Cambodia, Vietnam, and Peninsular Malaysia.

\section{Order Siluriformes}

\section{Family Sisoridae}

Glyptothorax fuscus Fowler 1934

\author{
Plate 10
}

Material examined: 1 ex., $40 \mathrm{~mm} \mathrm{SL}$, collected under the leaf piles however, the specimen was not retained, coll: M. Aqmal-Naser, 02 September 2014. UMTZC 8010

Remarks: Genus Glyptothorax is one of the most diverse genus in the family Sisoridae with 70 valid species (Ng \& Hadiaty, 2009). Based on Shushen (1986), the author classified and divided this genus into Superglyptothorax, Paraglyptothorax, and Glyptothorax with special attention to the plaited skin folds on the paired fins along with dorsal spine morphology but were not embraced by most of the ichthyologist as it was not tested through phylogenetic analysis (Jiang et al., 2011). Previously, some studies were using specimen labeled as Glyptothorax major instead of Gylptothorax fuscus for the specimens collected in Peninsular Malaysia and this is inaccurate because G. major is restricted to Borneo (Ng \& Lim, 1997). G. fuscus has a robust body with irregular blotches and spots. The body has a rusty brown coloration with a pale mid-lateral line. Differ to its congener, G. platypogonoides which having a more slender caudal peduncle. A bottom species usually found beneath leaf litter, driftwood, or pebbles in flowing water. The species can be found throughout Peninsular Malaysia and Thailand.

\section{Family Siluridae}

\section{Silurichthys schneideri Volz 1904}

\section{Plate 11}

Material examined: 1 ex., $80 \mathrm{~mm}$ SL, under vegetation on the streambank, coll: M. Aqmal-Naser, 02 September 2014. UMTZC 8011

Remarks: The species from the genus Silurichthys can be found in freshwater swamps and forest streams of Southeast Asia (Sundaland) only. Some of the species also may look similar to another silurid species from the genus Pterocryptis, however differ by having merged anal and caudal fins $(\mathrm{Ng} \& \mathrm{Tan}$, 2011). There were at least three known species of silurids in Peninsular Malaysia which are Silurichthys hasselti, Silurichthys schneideri, and Silurichthys indragiriensis. Silurichthys schneideri can be differentiated from its congener by having $56-68$ anal fin rays while Silurichthys hasselti with $46-56$ anal fin rays and Silurichthys indragiriensis with 45 - 46 anal fin rays. Both Silurichthys hasselti and Silurichthys indragiriensis can further be 
differentiated according to the upper caudal lobe / lower caudal lobe ratio - Silurichthys hasselti $(1: 2)$ and Silurichthys indragiriensis (1:4 - 1:6). Silurichthys schneideri is distributed in north Peninsular Malaysia, north Sumatra, south Cambodia, and south and southeast Thailand, Silurichthys hasselti in south Peninsular Malaysia, Singapore, Bangka, and Java while and Silurichthys indragiriensis in a swamp in Peninsular Malaysia and Sumatra (Ng \& Tan, 2011). This species has been reported from Langkawi Island by Ahmad and Lim (2006). Record from Perlis State Park identified as S. ingragiriensis by Ahmad and Samat (2005) could be this species. In their paper, the species was listed as such in Table 1 (Ahmad \& Samat, 2005; page 336) but in the plate given, it was labeled as $S$. hasselti and probably representing $S$. schneideri.

\section{Family Clariidae}

\section{Clarias leiacanthus Bleeker 1851}

\section{Plate 12}

Material examined: 1 ex., $120 \mathrm{~mm}$ SL, from stagnant water near the boulders and leaf litters, the specimen was not retained, coll: M. Aqmal-Naser, 02 September 2014. UMTZC 8012

Remarks: Currently, eight species of catfishes from the genus Clarias have been recorded in Peninsular Malaysia namely Clarias batrachus, Clarias batu, Clarias leiacanthus, Clarias macrocephalus, Clarias meladerma, Clarias nieuhofii, Clarias sulcatus, and Clarias gariepinus (introduced species). Clarias sulcatus is an endemic species to Pulau Redang (Ng, 2004) while Clarias batu is endemic to Pulau Tioman (Lim \& Ng, 1999). Clarias leiacanthus, (forest catfish) can be differentiated from other species which has an angular occipital process with a rounded tip. Dorsal fin rays with $70-$ 74 rays while anal fin with $60-63$ rays and not fused with caudal fin. The species can be found in clear water and flowing streams in the forest with rocky or sandy substrate. Usually found hiding beneath the rocks or roots. A common species throughout Peninsular Malaysia mainly caught for cheap protein source by the local people. Other seven catfishes found in Peninsular Malaysia has a different number of dorsal and anal fin rays as follows; Clarias batrachus (dorsal; 63 - 75, anal; $47-57$ ), Clarias batu (dorsal; 67 - 75, anal; 61 - 70), Clarias macrocephalus (can easily be distinguished by its rounded occipital process and broadhead ), Clarias meladerma (dorsal; 68 - 72, anal; 52 - 61) Clarias nieuhofii (dorsal; 87 - 106, anal; 63 - 93) Clarias sulcatus (dorsal; 72 - 80, anal; $56-64$ ) and Clarias gariepinus (dorsal; 61 - 80, anal; $45-65$ ).
Family Bagridae

\section{Batasio fluviatilis (Day 1888)}

Plate 13

Material examined: 3 ex., $22-40 \mathrm{~mm}$, from the main stream in shallow water, coll: M. Aqmal-Naser, 02 September 2014. UMTZC 8013

Remarks: At present, there were 18 valid species from the genus Batasio found in South and Southeast Asia (Plamootil, 2015). They can be differentiated by other members from family Bagridae with large sensory pores on the head and bar-like ectopterygoid (Mo, 1991). However, Batasio fluviatilis is the only known species that occur in Peninsular Malaysia, up to the isthmus of Kra but the distribution might be expanded to the north of the Tapi river basin ( $\mathrm{Ng} \&$ Kottelat, 2001). The species has 7 dorsal soft rays and $4-5$ anal spines. Possess obliques black predorsal bars on the side of the body below adipose fin base. This species also might be confused as different species when they were juvenile and adult. Batasio fluviatilis exhibit ontogenic color changes along with their development and growth. Newly hatched fish did not have pigment but begin to have a color pattern with two dark vertical bars on the head pass through the eye and one vertical bar on the dorsum. The juvenile then will have four dark bars -1) on the head passing the eyes, 2) running indirectly anterior on the dorsal fin, 3) anterior third of adipose fin and 4) posterior extremity at the caudal peduncle. The adult will have a dark brown spot below the anterior third of adipose fin as the bars fade following with the age (see $\mathrm{Ng}$ \& Kottelat, 2001). This species was also found in Langkawi Island and Perlis State Park but was reported as B. havmolleri by Ahmad and Lim (2006) and Ahmad and Samat (2005), respectively.

\section{Hemibagrus capitulum (Popta 1904)}

Plate 14

Material examined: 1 ex., $65 \mathrm{~mm}$ SL, main stream under vegetation on the streambank, coll: M. Aqmal-Naser, 02 September 2014. UMTZC 8014

Remarks: There were eight species groups for Asian bagrid catfish with 32 valid species after comprehensive revision by $\mathrm{Ng}$ and Kottelat (2013). The eight species group including $H$. baramensis, $H$. guttatus, $H$. menoda, $H$. nemurus, $H$. olyroides, $H$. planiceps, $H$. pluriradiatus, and $H$. wyckii species groups. In all, 11 species can be found in Malaysia; Borneo (H. bongan, H. hoevenii, H. baramensis, $H$. sabanus, $H$. semotus, $H$. fortis, $H$. capitulum), and Peninsular Malaysia (H. capitulum, H. divaricatus, 
H. gracilis, $H$. wyckii) with additional one introduced species $-H$. wyckioides. In Peninsular Malaysia, three species groups were known to occur in its natural river basins namely $H$. nemurus species group (H. capitulum), H. planiceps species group (H. divaricatus and $H$. gracilis), and $H$. wyckii species group (H. wyckii and $H$. wyckioides). Most of the literature in Peninsular Malaysia misidentified $H$. capitulum as $H$. nemurus where the distribution is restricted to Java ( $\mathrm{Ng} \&$ Kottelat, 2013). Hemibagrus capitulum has adpressed dorsal fin reaching adipose fin origin. Forked caudal fin with both lobes rounded and rounded anal fin. For $H$. planiceps species groups, $H$. divaricatus is restricted to western Peninsular Malaysia while $H$. gracilis can be found in eastern Peninsular Malaysia (see Ng \& Kottelat, 2013 for details). Another species group, H. wyckii is the easiest to identify by having a dark grey body with a white marginated line at its caudal fin while $H$. wyckioides has a reddish-orange caudal fin.

\section{Order Beloniformes}

\section{Family Zenarchopteridae}

Hemirhamphodon pogonognathus (Bleeker 1853)

Plate 15

Material examined: 3 ex., 20 - $40 \mathrm{~mm}$ SL, mainstream and unnamed tributaries in the shallow and stagnant water, coll: M. Aqmal-Naser, 02 September 2014. UMTZC 8015

Remarks: Family Zenarchopteridae consists of three genus which is Hemirhamphodon, Dermogenys, and Nomorhampus. Genus Hemirhampodon can be distinguished from its congener which has pleural ribs that start on the $2^{\text {nd }}$ vertebrate and the presence of anterior directed teeth along the jaw (Anderson \& Collette, 1991). Hemirhamphodon pogonognathus has a lower jaw that is much longer than the upper jaw and sometimes the anterior tips are bent downwards. The species is widely distributed (Roberts, 1989) and can be found in Malay Peninsula, Singapore, Western Borneo, and Natuna. Currently, there were nine valid species from the genus Hemirhamphodon with a restricted range of distribution (Tan \& Lim, 2013) as follows: H. byssus (southern Sarawak), H. kuekenthali (Central Sarawak), H. kapuensis (middle and lower Kapuas basin), H. chrysopunctatus (Central Kalimantan), H. tengah (Central Kalimantan), $H$. sesamum (South Kalimantan), H. kecil (lower Mahakam), H. phaiosoma (Banka, Western Kalimantan) and the common $H$. pogonognathus. However, H. pogonognathus group could have a cryptic species complex. A study by Lim et al. (2016) stated that $H$. pogonognathus species complex in Peninsular Malaysia may potential has a new species since the specimen from Kelantan has separated cluster based on $\mathrm{CO} 1$ gene trees from the real $H$. pogonognathus group.

\section{Order Synbrachiformes}

Family Mastacembelidae

\section{Macrognathus maculatus (Cuvier, in Cuvier \& Valenciennes 1832)}

Plate 16

Material examined: 1 ex., $50 \mathrm{~mm} \mathrm{SL}$, under leaf litters in the main stream, coll: M. Aqmal-Naser, 16 May 2014. UMTZC 8016

Remarks: There are three species from the genus Macrognathus in Peninsular Malaysia including Macrognathus tapirus, Macrognathus maculatus, and Macrognathus circumcinctus. Macrognathus maculatus is a common species, distributed in the Mekong river basin, Vietnam, Indonesia, and Malaysia. The species is always confused with its congener, $M$. circumcinctus due to their similar shape, colors, and patterns. Both species share the same 6 finger-like projection at the nostril, however can be differentiated apart where $M$. maculatus has 52 - 66 dorsal-fin rays (45-58 in M. circumcinctus) and $12-31$ dorsal fin spines. Adult M. maculatus does not has bars on the body and sometimes faint in the juvenile form while the bars in the M. circumcinctus are always present (Rainboth, 1996).

\section{Mastacembelus tinwini Britz 2007}

Plate 17

Material examined: 1 ex., $100 \mathrm{~mm}$ SL, under leaf litters in the main stream, coll: M. Aqmal-Naser, 08 April 2014. UMTZC 8017

Remarks: About five species from the genus Mastacembelus occur in Peninsular Malaysia namely Mastacembelus erythrotaenia, Mastacembelus favus, Mastacembelus notophthalmus, Mastacembelus tinwinii, and Mastacembelus unicolor. Mastacembelus tinwinii has a $3-5$ interrupted black longitudinal line, broken up in blotches on the body side. The soft dorsal anal and caudal fins have a white margin (Britz, 2007). In all, two species - Mastacembelus favus and Mastacembelus notophthalmus are likely to be confused with Mastacembelus tinwinii due to their similar-looking patterns. Mastacembelus favus has a yellow broad connected network of patterns that almost extend onto its abdomen while Mastacembelus notophthalmus has a reticulated dark pattern which is more obvious in the ventral half of 
the body, with irregular and a small light mark on the dorsal part. Ahmad and Samat (2005) reported the presence of Mastacembelus sp. in Perlis State Park and it could potentially be this species.

\section{Order Anabantiformes}

\section{Family Osphronemidae}

\section{Betta pugnax (Cantor 1849)}

Plate 18

Material examined: 3 ex., $34-65 \mathrm{~mm}$ SL, main stream and unnamed tributaries near the main road coll: $\mathrm{M}$. Aqmal-Naser, 16 May 2014. UMTZC 8018

Remarks: Genus Betta has the most number of species in the family Osphronemidae (Britz, 2001) and in Peninsular Malaysia, 15 species had been recorded including the recently described species from blackwater swamps, Betta omega (Tan \& Ahmad, 2018). Most of the species within this genus sharing few similarities of diagnostic characters and has been classified into 13 species group (Tan \& Ng, 2005). The species group including the Betta belica group, Betta pugnax group, Betta akarensis group, Betta unimaculata group, Betta picta group, Betta splendens group, Betta coccina group, Betta waseri group, Betta edithae group, Betta foerschi group, Betta anabatoides group, and Betta albimarginata group. Ten species groups can be found in Malaysia; Borneo - Betta pugnax group (Betta lehi), Betta akarensis group (Betta akarensis, Betta balunga, Betta chini, Betta ibanorum, Betta obscura), Betta unimaculata group (Betta macrostoma, Betta ocellata, Betta gladiator), Betta picta group (Betta taeniata), Betta coccina group (Betta brownorum) and Peninsular Malaysia - Betta bellica group (Betta bellica), Betta pugnax group (Betta pugnax, Betta pulchra, Betta stigmosa), Betta splendens group (Betta imbellis), Betta coccina group (Betta coccina, Betta tusyae, Betta persephone, Betta livida), Betta waseri group (Betta waseri, Betta hipposeroides, Betta pi, Betta omega). Betta pugnax possesses a lanceolate shape caudal fin with no dark edge, with iridescent greenish-blue opercle scales on its body. It can be further differentiated from other species in the group by the absence of dark mark below the postorbital stripe on its opercle, the presence of chin-bar and dorsal transverse bar, with lateral line scale of $28-31$ and $25-28$ anal fin rays. It is a common species, widely distributed in Peninsular Malaysia forest streams.

\section{Family Channidae}

\section{Channa lucius (Cuvier, in Cuvier \& Valenciennes 1831)}

Plate 19

Material examined: 3 ex., SL $25-80 \mathrm{~mm}$ SL, a main stream near the riverbank under a shaded area, coll, M. Aqmal-Naser, 22 July 2014. UMTZC 8019

Remarks: The species from this genus are mainly used in ornamental fish trade and food. Seven species were known to occur in Peninsular Malaysia namely Channa bankanensis, Channa limbata, Channa lucius, Channa marulioides, Channa melasoma, Channa micropeltes, and Channa striata. According to Conte-Grand et al. (2017), four species groups had understudied diversity which are Channa marulius group, Channa striata group, Channa bankanensis group, and Channa gachua group. Channa lucius can be differentiated from other congener species by having a black spot on the operculum with a short head, convex dorsal part. Having $37-41$ dorsal soft rays and 25 - 30 anal soft rays. The adult has black blotches that are rounded and not continuous and the belly has obliques bars. The species is widely distributed through Myanmar, Mekong river basins, Sunda islands, and Peninsular Malaysia. However, a detailed study is needed to compare the morphometric and meristematic aspect of Channa lucius from other populations. This also applied to Channa striata where there had been a deep intraspecific divergence of the species between samples from different regions. Further genetic and morphological analysis is urgently needed (ConteGrand et al., 2017).

\section{Channa limbata (Hamilton 1822)}

Plate 20

Material examined:3 ex., 40 - $85 \mathrm{~mm}$ SL, main stream and unnamed tributaries near the main road, $M$. Aqmal-Naser, 22 July 2014. UMTZC 8020

Remarks: The species has a 38 - 40 lateral line scale, 31 - 35 dorsal-fin rays, and $21-24$ anal fin rays. Juvenile usually has transverse bars but faded away as it grows. The adult male has the prominent color of orange to reddish dorsal and anal fins. Previously, the species was reported as Channa gachua and it is a species complex that has two separated lineages (Conte-Grand et al., 2017). The true Channa gachua is distributed in the West IndoBurma range - India, Bangladesh, Sri Lanka, Nepal, 
and Rakhine (Myanmar) while the other lineage is distributed in the East Indo-Burma region including Vietnam, South China, Myanmar, south Indonesia, Thailand, and Malaysia. It was suggested that the species in the east region of Indo-Burma is Channa limbata (Conte-Grand et al., 2017). All previously reported species of $C$. gachua in Peninsular Malaysia should be now known as $C$. limbata (Zakaria-Ismail et al., 2019).

\section{CONCLUSION}

Fish fauna in Ulu Paip Eco-Park Forest, Gunung Bongsu Forest Reserve, Kedah is considered low compared to another study as different methods for the fish collection were used. Most of the species collected can be found in pristine habitats and have ornamental values. As this area facing several landuse changes, proper management and conservation plans should be initiated and executed to ensure the preservation of natural habitat and ecotourism activities.

\section{ACKNOWLEDGEMENTS}

We would like to thank Universiti Malaysia Terengganu for providing the facilities to conduct this study. Thanks to Amirul, Amirah, Aisha, and Azira for their assistance during the sampling.

\section{REFERENCES}

Ahmad, A. \& Lim, K.K.P. 2006. Inland fishes recorded from the Langkawi Islands, Peninsular Malaysia. Malayan Nature Journal, 59(1): 103120.

Ahmad, A. \& Samat, A. 2005. Additional records of freshwater fishes of Perlis State Park, Peninsular Malaysia. Malayan Nature Journal, 57(3): 329345.

Ahmad, A., Nek, S.A.R., Shah, A.S.R.M., Sah, S.A.M. \& Samat, A. 2006. The ichthyofauna of Gunung Jerai, Kedah. Journal of Wildlife and Parks, 23: 63-70.

Ahmad, A.B., Zaini, N.R., Nayan, N.A.M., FahmiAhmad, M., Rizal, S.A. \& Yusuf, Y. 2018a. Freshwater fish diversity of Sungai Setiu, Terengganu, Peninsular Malaysia. Malayan Nature Journal, 70(4): 499-507.
Ahmad, A.B., Fahmi-Ahmad, M. \& Rizal, S.A. 2018 b. Freshwater fishes of Sungai Chantek, Pasir Akar, Besut, Terengganu, Peninsular Malaysia. Journal of Agrobiotechnology, 9(1): 41-49.

Anderson, W.D. \& Collette. B.B. 1991. Revision of the freshwater viviparous halfbeaks of the genus Hemirhamphodon (Teleostei: Hemiramphidae). Ichthyological Explorations of Freshwaters, 2: 151-176.

Aqmal-Naser, M. \& Ahmad, A.B. 2018a. Checklist of the inland fish community at Kampung Asah and Kampung Mukut, Tioman Island, Pahang, Peninsular Malaysia. Journal of Wildlife and Parks, 33: 95-106.

Aqmal-Naser, M. \& Ahmad, A.B. 2018b. Checklist of fishes in rice agroecosystem in Seberang Prai Tengah, Pulau Pinang, Peninsular Malaysia with notes on the emergence of the introduced species. Malayan Nature Journal, 70(4): 477488.

Britz, R. 2001. The genus Betta -monophyly and intrarelationships, with remarks on the subfamilies Macropodinae and Luciocephalinae (Teleostei: Osphronemidae). Ichthyological Exploration of Freshwaters, 12(4): 305-318.

Britz, R. 2007. Two new species of Mastacembelus from Myanmar (Teleostei: Synbranchiformes: Mastacembelidae). Ichthyological Exploration of Freshwaters, 18(3): 257.

Conte-Grand, C., Britz, R., Dahanukar, N., Raghavan, R., Pethiyagoda, R., Tan, H.H., Hadiaty, R.K., Yaakob, N.S. \& Rüber, L. 2017. Barcoding snakeheads (Teleostei, Channidae) revisited: Discovering greater species diversity and resolving perpetuated taxonomic confusions. PloS One, 12(9): e0184017.

Dias, M.S., Magnusson, W.E. \& Zuanon, J. 2010. Effects of reduced impact logging on fish assemblages in Central Amazonia. Conservation Biology, 24(1): 278-286.

Fahmi-Ahmad, M., Theng, C.C.M., Nor, S.A.M. \& Ahmad, A. 2020. Deciphering species-group taxonomic complexity of common, Barbodes binotatus and saddle barbs, B. banksi in Peninsular Malaysia. Malaysian Journal of Fundamental and Applied Sciences, 16(5): 536543.

Fang, F. 2003. Phylogenetic analysis of the Asian cyprinid genus Danio (Teleostei, Cyprinidae). Copeia, (4): 714-728. 
Fang, F., Noren, M., Liao, T.Y., Källersjö, M. \& Kullander, S.O. 2009. Molecular phylogenetic interrelationships of the south Asian cyprinid genera Danio, Devario and Microrasbora (Teleostei, Cyprinidae, Danioninae). Zoologica Scripta, 38(3): 237-256.

Jiang, W., Ng, H.H., Yang, J. \& Chen, X. 2011. Monophyly and phylogenetic relationships of the catfish genus Glyptothorax (Teleostei: Sisoridae) inferred from nuclear and mitochondrial gene sequences. Molecular Phylogenetics and Evolution, 61(2): 278-289.

Jones III, E.D., Helfman, G.S., Harper, J.O. \& Bolstad, P.V. 1999. Effects of riparian forest removal on fish assemblages in southern Appalachian streams. Conservation Biology, 13(6): 1454 1465.

Kamaruddin, K. \& Nor, S.A.M. 2010. A molecular study of Puntius lateristriga (Valenciennes, 1842) in Peninsular Malaysia based on 16S rRNA mitochondrial gene, in: The $7^{\text {th }}$ IMT-GT UNINET $\&$ The $3^{\text {rd }}$ Joint International PSU-UNS Conferences. Prince of Songkla University, Hat Yai, Songkhla, Thailand.

Khaironizam, M.Z., Zakaria-Ismail, M. \& Armbruster, J.W. 2015. Cyprinid fishes of the genus Neolissochilus in Peninsular Malaysia. Zootaxa, 3962(1): 139-157.

Kottelat, M. 2005. Rasbora notura, a new species of cyprinid fish from the Malay Peninsula (Teleostei: Cyprinidae). Ichthyological Exploration of Freshwaters, 16(3): 265-270.

Kottelat, M. 2013. The fishes of the inland waters of Southeast Asia: a catalogue and core bibliography of the fishes known to occur in freshwaters, mangroves and estuaries. Raffles Bulletin of Zoology, 27: 1-663.

Kottelat, M. 2020. Ceratogarra, a genus name for Garra cambodgiensis and G. fasciacauda and comments on the oral and gular soft anatomy in labeonine fishes (Teleostei: Cyprinidae). Raffles Bulletin of Zoology, 35: 156-178.

Kottelat, M. 2001. Fishes of Laos. WHT Publications Ltd., Sri Lanka. 198 pp.

Kottelat, M., Whitten, A.J., Kartikasari, S.N. \& Wirjoatmodjo, S. 1993. Freshwater fishes of Western Indonesia and Sulawesi. Periplus Editions, Hong Kong. 221 pp.

Lee, P.K.Y., Shah, A.S.R.M. \& Khaironizam, M.Z. 2013. Assessment of freshwater fisheries in Ulu Muda, Kedah, Malaysia, WWF Technical Report. WWF, Kuala Lumpur.

Liao, T.Y. \& Kullander, S.O. 2013. Phylogenetic significance of the kinethmoid associated $\mathrm{Y}$ shaped ligament and long intercostal ligaments in the Cypriniformes (Actinopterygii: Ostariophysi). Zoologica Scripta, 42(1): 71-87.
Lim, H., Abidin, M.Z., Pulungan, C.P., de Bruyn, M. \& Nor, S.A.M. 2016. DNA barcoding reveals high cryptic diversity of the freshwater halfbeak genus Hemirhamphodon from Sundaland. PLoS One, 11(9): e0163596.

Lim, K.K.P. \& Ng, H.H. 1999. Clarias batu, a new species of catfish (Teleostei: Clariidae) from Pulau Tioman, Peninsular Malaysia. Raffles Bulletin of Zoology, 47: 157-168.

Lumbantobing, D.N. 2014. Four new species of Rasbora of the Sumatrana group (Teleostei: Cyprinidae) from northern Sumatra, Indonesia. Zootaxa, 3764(1): 1-25.

Martin Smith, K. 1998. Biodiversity patterns of tropical freshwater fish following selective timber extraction: a case study from Sabah, Malaysia. Italian Journal of Zoology, 65(S1): 363-368.

Mo, T.A. 1991. Anatomy, relationships and systematics of the Bagridae (Teleostei: Siluroidei) with a hypothesis of siluroid phylogeny. Theses Zoology, 17: 1-216.

Ng, C.K.C., Lim, T.Y., Ahmad, A.B. \& Khaironizam, M.Z. 2019. Provisional checklist of freshwater fish diversity and distribution in Perak, Malaysia, and some latest taxonomic concerns. Zootaxa, 4567(3): 515-545.

Ng, H.H. \& Hadiaty, R.K. 2009. Glyptothorax ketambe, a new catfish (Teleostei: Sisoridae) from northern Sumatra. Zootaxa, 2085(1): 61-68.

Ng, H.H. \& Kottelat, M. 2001. A review of the genus Batasio (Teleostei: Bagridae) in Indochina, with the description of $B$. tigrinus sp. n. from Thailand. Revue suisse de Zoologie, 108(3): 495-512.

Ng, H.H. \& Kottelat, M. 2013. Revision of the Asian catfish genus Hemibagrus Bleeker, 1862 (Teleostei: Siluriformes: Bagridae). Raffles Bulletin of Zoology, 61(1): 205-291.

Ng, H.H. \& Tan, H.H. 2011. Silurichthys ligneolus, a new catfish (Teleostei: Siluridae) from southern Borneo, Indonesia. Zootaxa, 2793: 56-62.

Ng, H.H. 2004. Clarias sulcatus, a new walking catfish (Teleostei: Clariidae) from Pulau Redang. Ichthyological Exploration of Freshwaters, 15(4): 289-294.

Ng, P.K. \& Lim, K.K. 1997. The diversity and conservation status of fishes in the nature reserves of Singapore. The Gardens' Bulletin Singapore, 49(2): 245-265.

Plamoottil, M. 2015. Batasio flavus, a new catfish species (Siluriformes: Bagridae) from Kerala, India. Journal of Research in Biology, 5(5): 1799-1808.

Rahman, N.A. 2017. Cubaan seludup balak gagal [WWW Document]. Berita Harian. URL https:// www.bharian.com.my/node/229873 (accessed 19.11.20). 
Rahman, N.A. 2018. Balak haram RM200,000, jentera disita [WWW Document]. Berita Harian. URL https://www.bharian.com.my/berita/kes/2018/03/ 399951/balak-haram-rm200000-jentera-disita (accessed 19.11.20).

Rainboth, W.J. 1996. FAO species identification field guide for fishery purposes. Food and Agriculture Organization of the United Nations, Rome. 256 pp.

Roberts, T.R. 1989. The freshwater fishes of Western Borneo (Kalimantan Barat, Indonesia). California Academy of Sciences, San Fancisco. 210 pp.

Rowe, D.K., Smith, J., Quinn, J. \& Boothroyd, I. 2002. Effects of logging with and without riparian strips on fish species abundance, mean size, and the structure of native fish assemblages in Coromandel, New Zealand, streams. New Zealand Journal of Marine and Freshwater Research, 36(1): 67-79.

Ryan, J.R. \& Esa, Y.B. 2006. Phylogenetic analysis of Hampala fishes (subfamily cyprininae) in Malaysia inferred from partial mitochondrial cytochrome b DNA sequences. Zoological Science, 23(10): 893-902.

Sah, A.S.R.M., Samat, A., Putih, K. \& Mansor, K.N.A. 2012. Notes on the freshwater fishes at selected headwater streams of the Ulu Muda Forest Reserve, Kedah Darul Aman. Malayan Nature Journal, 64(3): 147-152.

Shah, A.S.R.M., Hashim, Z.H. \& Sah, S.A.M. 2009. Freshwater fishes of Gunung Jerai, Kedah Darul Aman: A preliminary study. Tropical Life Sciences Research, 20(2): 59-70.

Shahriza, S. \& Ibrahim, J. 2014. A preliminary checklist of amphibians of Ulu Paip Recreational Forest, Kedah, Malaysia. Check List, 10: 253-259.

Shushen, L. 1986. The systematic classification and distribution and evolution for Glyptothorax Blyth. Journal of Yunnan University (1): 20.
Tan, H.H. \& Ahmad, A.B. 2018. Betta omega, a new species of black water fighting fish (Teleostei: Osphronemidae) from Malaysia. Raffles Bulletin of Zoology, 66: 402-407.

Tan, H.H. \& Lim, K.K. 2004. Inland fishes from the Anambas and Natuna Islands, South China Sea, with description of a new species of Betta (Teleostei: Osphronemidae). The Raffles Bulletin of Zoology. Supplement No. 11:107-115.

Tan, H.H. \& Lim, K.K. 2013. Three new species of freshwater halfbeaks (Teleostei: Zenarchopteridae: Hemirhamphodon) from Borneo. Raffles Bulletin of Zoology, 61(2): 735-747.

Tan, H.H. \& Ng, P.K. 2005. The fighting fishes (Teleostei: Osphronemidae: genus Betta) of Singapore, Malaysia and Brunei. The Raffles Bulletin of Zoology, (13): 43-99.

Tan, H.H., Low, B.W., Yeo, D.C. \& Lim, K.K. 2015. An update to the inland fishes of Pulau Tioman, Malaysia. Raffles Bulletin of Zoology, 63: 555563.

Tan, M. \& Armbruster, J.W. 2018. Phylogenetic classification of extant genera of fishes of the order Cypriniformes (Teleostei: Ostariophysi). Zootaxa, 4476(1): 6-39.

Tweedie, M.W.F. 1961. Notes on Malayan fresh-water fishes 9. Regional differentiation in the colour pattern of Puntius lateristriga $(\mathrm{C} \& \mathrm{~V})$. The Bulletin of the Raffles Museum, 26: 178-182

van der Laan. \& Fricke, R. 2014. Family-group names [WWW Document]. URL http://www. calacademy.org/scientists/catalog-of-fishesfamily-group-names/ (accessed 10.11.2020).

Zakaria-Ismail, M., Fatimah, A. \& Khaironizam, M.Z. 2019. Fishes of the freshwater ecosystems of Peninsular Malaysia. LAP Lambert Academic Publishing, Mauritius. 356 pp. 